\title{
THE IMPORTANCE OF COUNTRY-OF- ORIGIN CONSTRUCT DIMENSIONS IN DESTINATION BRAND BUILDING
}

\section{VAŽNOST DIMENZIJA KONSTRUKTA ZEMLJE PODRIJETLA U IZGRADNJI MARKE DESTINACIJE}

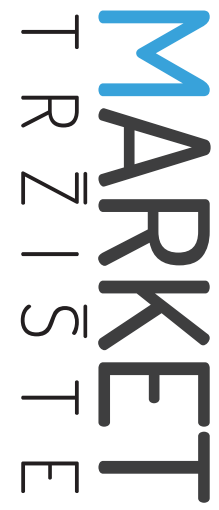

\author{
Market-Tržište \\ Vol. 33, No. 2, 2021, pp. 221-238 \\ UDK 658.626:338.48-44(73)(497.5) \\ DOI http://dx.doi.org/10.22598/mt/2021.33.2.221 \\ Preliminary communication
}

\section{Zoran Krupkaa, Mateja Mirt ${ }^{b}$, Đurđana Ozretić-Došenc}

a University of Zagreb, Faculty of Economics \& Business, Trg J. F. Kennedyja 6, 10000 Zagreb, CROATIA, e-mail: zkrupka@efzg.hr

${ }^{b}$ Coca Cola Hellenic Bottling Company, Milana Sachsa 1, 10000 Zagreb, CROATIA

c University of Zagreb, Faculty of Economics \& Business, Trg J. F. Kennedyja 6, 10000 Zagreb, CROATIA, e-mail: dozretic@efzg.hr

\begin{abstract}
Purpose - The primary purpose of this paper is to analyze the relationship between the country-of-origin (COO) construct and destination brand building (DBB) to reveal whether the $\mathrm{COO}$ construct and its dimensions are important for DBB. More specifically, the paper explores whether $\mathrm{COO}$ construct dimensions can impact destination branding.
\end{abstract}

Design/Methodology/Approach - The research was conducted using a self-administered questionnaire on a sample of 409 respondents from the United States and Croatia. SPSS was used for data analysis.

Findings and implications - While the $\mathrm{COO}$ is relevant for DBB, it cannot be used in the same manner as in product/service branding. Certain $\mathrm{COO}$ dimensions which are extremely important for product/service brands (e.g., level of technological development, standard of living) are not as critical for DBB. The political situation and perceived safety are $\mathrm{COO}$ dimensions that have proven to be important in the context of DBB.

Limitations - The main limitation of the paper arises from sampling, relying on Facebook and Linkedln for questionnaire distribution.

\section{Sažetak}

Svrha - Glavna je svrha ovoga rada istražiti odnos između konstrukta zemlje podrijetla i izgradnje marke destinacije kako bi se saznalo jesu li konstrukt zemlje podrijetla i njegove dimenzije važni za izgradnju marke destinacije. Znači, ovim radom se istražuje utječu li dimenzije konstrukta zemlje podrijetla na marku destinacije.

Metodološki pristup - Istraživanje je provedeno uz pomoć upitnika na uzorku od 409 ispitanika iz SAD-a i Hrvatske. Za analizu podataka korišten je SPSS.

Rezultati i implikacije - Zemlja podrijetla važna je za izgradnju marke destinacije, ali se ne može koristiti na isti način kao za izgradnju marke proizvoda/usluge. Neke dimenzije zemlje podrijetla koje su izrazito važne za marku proizvoda/usluge (npr. razina tehnološke razvijenosti, životni standard) nisu toliko važne za marku destinacije. Politička situacija i percipirana sigurnost dimenzije su zemlje podrijetla koje su se pokazale važnima u izgradnji marke destinacije.

Ograničenja - Glavna su ograničenja ovog rada prigodni uzorak te korištenje Facebooka i Linkedlna kao platformi za distribuciju upitnika.

Doprinos - Ovim istraživanjem raščlanjujemo zemlju podrijetla kao konstrukt i istražujemo utjecaj njegovih sastavnica na izgradnju marke destinacije. 
Originality - With this research, we are decomposing the $\mathrm{COO}$ construct and investigating the impact of its dimensions on DBB.

Keywords - country of origin, brand building, destination brand
Ključne riječi - zemlja podrijetla, izgradnja marke, marka destinacije 


\section{INTRODUCTION}

Tourism, as one of the fastest-growing industries globally (www2.unwto.org), has become important even for countries that were not traditionally considered to be tourism-oriented. To maintain growth in a highly competitive global market, countries, cities, villages, and man-made resorts, or destinations (Pike, 2004), need to differentiate themselves. Apart from the traditional forms of differentiation such as accommodation, restaurants, entertainment facilities, etc. (Tasci, Gartner \& Cavusgil, 2007), the destination's country of origin (COO) might be an essential factor in the tourist decision-making process.

Destination brand building (DBB) is a highly complex activity. It requires an integrated approach to branding, encompassing expectations, experiences, and memories in the minds and hearts of tourists (Boo, Busse \& Baloglu, 2009; Blain, Levy \& Ritchie, 2005). According to Ritchie and Ritchie (1998), a destination brand is a promise of an unforgettable feeling that will remain in the mind and heart of a tourist having consumed the destination and after return to their hometown. Therefore, destination brand image is a critical factor influencing tourist attitudes toward a destination (Veasna, 2013; Jalilvand, Samiei \& Dini, 2012).

This paper focuses on the relationship between the COO construct and DBB to analyze whether different COO dimensions can have an impact on DBB.

$\mathrm{COO}$ is usually defined as an extrinsic product/ service attribute indicating the country where a product/service was made/provided, assembled, or both (Meng, Nasco \& Clark, 2007; Han \& Terpstra, 1988; Bilkey \& Nes, 1982). As a marketing construct, $\mathrm{COO}$ has been the subject of numerous studies for more than 50 years (e.g., Schooler, 1965; Nagashima, 1970; Erickson, Johansson \& Chao, 1984; Ozsomer \& Cavusgil, 1991), most of which deal with its influence on the consumer decision-making process and product evalua- tion (e.g., Diamantopoulos, Schlegelmilch \& Palihawadana, 2011; Piron, 2000). In the area of destination branding, Nadeau, Heslop, O'Reilly, and Luk (2008) studied the overlapping of product-country image and destination image within the broader country image context. To the best of the authors' knowledge, there has been no research of the importance of the $\mathrm{COO}$ construct and its influence on DBB. Hence, this paper attempts to fill the research gap.

The theoretical background and hypothesis development follow the introductory part of the paper. Then, methods applied for data collection and analysis are presented, followed by a discussion of the results of hypothesis testing and key findings. In the concluding part, theoretical and managerial implications are outlined, together with the research limitations and an identification of possible future research streams.

\section{THEORETICAL BACKGROUND AND HYPOTHESIS DEVELOPMENT}

Many attributes are used in building destination brands, for instance, natural wonders, climate, nightlife, pricing, history, accommodation, destination accessibility, shopping possibilities, hospitality, and gastronomy (Batat, 2021; Tóth, Dávid \& Vasa, 2014; Kinley, Forney \& Kim, 2012; Echtner \& Ritchie, 2003). In line with Balakrishnan, Nekhili, and Lewis's supposition (2011), we assume that the COO construct (as in the case of products/ services) can also be considered one of those attributes.

$\mathrm{COO}$ and its image are measured through the dimensions of the economic and political situation (Martin \& Eroglu, 1993), the level of technological development and industrialization (Allred, Chakraborty \& Miller, 1999; Lin \& Chen, 2006), the standard of living and the country's popularity (Lin \& Chen, 2006), product quality (Martin \& Eroglu, 1993), and perceived safety 


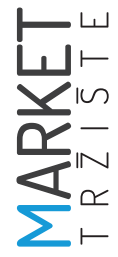

(Marting \& Eroglu, 1993; Chowdhury et al., 2017). In order to achieve its intended purpose to analyze whether and to which extent the dimensions of the COO can impact DBB, this paper considers the evaluations of those dimensions by tourists themselvers.

\section{Economic situation}

A country's economic situation shows how efficiently the government manages its resources (Pappu, Quester \& Cooksey, 2007), but more importantly, it reveals the country's economic stability (Lin \& Chen, 2006). Indicators of economic stability, including GDP per capita, the unemployment rate, public expenditure, public debt, imports/exports, exchange rate stability, etc., influence the creation of the COO image (Stutely, 2007). However, it is not known how many tourists explore and familiarize themselves with those indicators before visiting a particular destination and to what extent the country's economic stability is a critical factor in their decision making. As Martin and Eroglu (1993) have proved, supported by findings of Kaynak, Kucukemiroglu, and Hyder (2000), a favorable economic situation has a positive effect on the COO image building. Accordingly, we propose the first hypothesis:

H1: Favorable economic situation of a destination's COO is important for favorable DBB.

\section{Political situation}

Political situation refers primarily to the country's political structure, and whether it operates under a capitalist or a centrally planned market system (Martin \& Eroglu, 1993). Allred et al. (1999) posit that the stability of the political situation is assessed with respect to politicians, potential conflicts, the level of a country's openness, membership in international organizations, relations with neighboring countries, etc. As the country's political situation, i.e., whether it is stable or not affect the COO image, it represents one of the most critical factors together with the economic situation (Pappu et al., 2007). Political instability increases the risk of terrorist at- tacks (Saha \& Yap, 2014). Furthermore, extreme indicators of political instability such as conflicts contribute to the decrease in the number of tourist arrivals in the country, so its tourism potential is not fully exploited (Alvarez \& Campo, 2014; Morakabati, 2013). In the context of DBB, the question of the importance of the political situation for tourists arises irrespective of whether they are first-time or repeat visitors of a destination. Therefore, the second hypothesis is formulated:

H2: Favorable political situation of a destination's COO is important for favorable DBB.

\section{Level of technological development}

Although life without technology is unimaginable for most consumers nowadays, when the first COO scales were developed, technology did not play such an essential role in the daily lives of people and companies (Allred et al., 1999). However, Allred et al. (1999) pinpoint the level of technological development, such as the development of the Internet and communication media, as an essential factor in creating the COO image. The importance of technology in tourism development has been observed in the last 30 years (Navío-Marco, Ruiz-Gómez \& Sevilla-Sevilla, 2018; Buhalis \& Low, 2008; Buhalis \& O'Connor, 2005) and, according to Xiang (2018), its impact on tourism and society can generally be classified into two periods: a) the era of digitalization (1997-2006), and b) the age of acceleration (from 2007 onwards). Although almost the entire world is technologically connected and there are no communication boundaries, there are still tourist destinations (primarily located in less developed countries) in which activities such as car rental, booking of accommodation, or excursions pose a challenge to tourists due to the low technological development of the countries concerned (Jadhav \& Mundhe, 2011). Therefore, the importance of technological development in DBB arises as a question, leading to the following assumption under $\mathrm{H3}$ : 
H3: Favorable level of technological development of a destination's $\mathrm{COO}$ is important for favorable DBB.

\section{Level of industrialization}

The level of industrialization was initially viewed within the constructs of social desirability or technological development (Martin \& Eroglu, 1993). However, Allred et al. (1999), and Lin and Chen (2006) consider it to be a separate factor in observing COO. The level of industrialization is often emphasized in the context of socially responsible business and indirectly through environmental pollution (Cherniwchan, 2012), which affects the quality of life and the number of tourists in a destination (Brahmasrene \& Wan Lee, 2017). According to research conducted by Lin and Chen (2006), a higher level of industrialization affects the $\mathrm{COO}$ image positively. However, it can be seen as a negative factor in attracting tourists when the adverse environmental impact is considered. Based on the above, the fourth hypothesis posits:

H4: Favorable level of industrialization of a destination's COO is important for favorable DBB.

\section{Standard of living}

The perception of how people live in a country affects the country's image (Pereira, Hsu \& Kun$d u, 2005)$, and ultimately its attractiveness as a tourist destination. In addition to GDP per capita, which is the most common indicator of the standard of living (Bérenger \& Verdier-Chouchane, 2007), other variables which are not included in the GDP per capita also serve as indicators. According to Dowrick, Dunlop, and Quiggin (2003), these fall under the Genuine Progress Indicator or GPI (consisting of the crime rate, divorce rate, volunteering percentages, existence of social classes, etc.) and Human Development Index or HDI (including life expectancy, literacy level, cultural diversity, immigration, emigration, etc.). Following the research of Martin and Eroglu (1993), and Lin and Chen (2006), GDP per capita, destination population, cultural diversity, labor costs, and the existence of social class- es are taken as variables in this study to measure the standard of living. Moreover, research conducted by Gartner (2004) showed that the brand equity of a tourist destination is also affected by the standard of living. Therefore, the fifth hypothesis is formulated as follows:

\section{H5: Favorable standard of living of a destination's COO is important for favorable DBB.}

\section{Product quality}

Unlike the economic and political situation or the level of industrialization which represent macro indicators of the $\mathrm{COO}$, product quality acts a a micro indicator (Listiana, 2015). Pecotich and Rosenthal (2001) state that the COO image refers to an opinion of a country as the place where the brand/product is created/produced and depends on the country's ability to support innovative companies producing technologically advanced and prestigious products (Pappu et al., 2007). In addition, Roth and Romeo (1992) define the COO image as the consumers' overall perception of the quality of products from a particular country. The problem that may arise is the subjectivity of quality as a category. The same product/service does not have to represent the same level of quality for different consumers (Kirchler, Fischer \& Hölzl, 2010). Therefore, the question to be answered is whether (and in what manner) experience with products from a particular country can influence DBB. In view of the foregoing, the sixth hypothesis posits:

H6: Favorable product quality of a destination's COO is important for favorable DBB.

\section{Popularity}

Popularity as a factor in creating the COO image was singled out by Lin and Chen (2006), who defined it as the level of confidence consumers have in using products/services from a particular country and the desire to reuse and/or own them. Accordingly, Listiana (2015) cites popularity as an essential element of creating loyalty to a specific brand, which is also applicable when building a destination brand. The ranking 


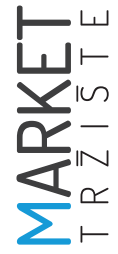

of countries by popularity is published by the World Tourism Organization (www2.unwto.org), with the main ranking criterion being the number of tourist arrivals within a year. Although the number of tourists is changing globally, there have been no significant changes in the list of the most visited countries. Since COO influences the brand building of products/services (Yasin, Noor \& Mohammad, 2007), we believe that it also affects DBB, which leads to the following hypothesis:

\section{H7: Favorable popularity of a destination's $\mathrm{COO}$ is important for favorable DBB.}

\section{Perceived safety}

As a factor in the existing $\mathrm{COO}$ literature, safety is often mentioned in the context of the political situation (Martin \& Eroglu, 1993). However, if we consider a continuous increase in the number of tourist arrivals, along with a rise in terrorist attacks and political instability worldwide, safety is becoming an essential factor for building the COO image and, accordingly, one with a potentially tremendous impact on DBB (Chowdhury, Raj, Griffin \& Clarke, 2017). Terrorist attacks and political instability undermine the number of tourist arrivals, the economic situation, and the standard of living in terms of leading to rising unemployment and inflation rates, reduced production, psychological problems of the population, etc. (Baker, 2014; Araña \& León, 2008). In addition to uncertainties arising from terrorism and political instability, it is important to look at safety in the context of the products/services consumed in the destination and the security of information, which has become a major issue nowadays (Zou \& Meng, 2020). Therefore, it is necessary to investigate the importance of safety for DBB, so we hypothesize as follows:

H8: Favorable perceived safety of a destination's COO is important for favorable DBB.

\section{Knowledge}

Finally, this paper investigates the way in which the level of knowledge about a destination in- fluences the importance of the destination's COO. According to Lee and Ganesh (1999), higher brand familiarity of the consumers means that their ability to assess its quality will be based on its characteristics more than on the external factors that may affect their impression. Furthermore, Ozretic-Dosen, Previsic, Krupka, Skare, and Komarac (2018) found better informed consumers to be more critical of the destination than those who are less informed. According to Han's (1989) "halo effect", the greater the knowledge about the product/service, the lesser the influence of $\mathrm{COO}$ on consumer behavior (Balakrishnan et al., 2011; Maheswaran, 1994). Hence, we posit that the same effect will be achieved in the case of a destination brand. Therefore, the ninth hypothesis claims:

H9: Greater knowledge of the destination brand reduces the importance of the destination's COO for DBB.

\section{METHODOLOGY AND RESULTS}

The paper relies on the quantitative method approach. The research was conducted on a convenience sample of 409 respondents from the United States (199) and Croatia (210), with data collection taking place in June and July of 2018. It has been proven (Ar \& Kara, 2014; Godey, 2012) that COO, for instance, affects consumer perception of product quality differently depending on whether the consumer comes from a developed or a developing country. Therefore, a heterogeneous sample of respondents was chosen for this study, in which respondents from the U.S. represented a developed country and those from Croatia represented a developing country. This is a similar methodological approach to that applied in the research conducted by Muhamad, Leong, and Isa (2017), and Klein, Ettenson, and Krishna (2006).

The respondents were approached through the social networks Facebook and Linkedln. A self-administered, highly structured questionnaire consisting of 37 statements and 6 demo- 
graphic questions was applied in English and Croatian. For Croatian respondents, statements were translated into the Croatian language using back-to-back translation (English-Croatian-English). The sample characteristics are shown in Table 1.

TABLE 1: Sample characteristics

Number (\%)

\begin{tabular}{|l|c|}
\hline Sex $(\mathbf{n = 4 0 9 )}$ & $123(30.1 \%)$ \\
\hline Male & $286(69.9 \%)$ \\
\hline Female & $6(1.5 \%)$ \\
\hline Age (n=409) & $160(39.1 \%)$ \\
\hline$<18$ & $130(31.8 \%)$ \\
\hline $18-24$ & $48(11.7 \%)$ \\
\hline $25-34$ & $31(7.6 \%)$ \\
\hline $35-44$ & $26(6.4 \%)$ \\
\hline $45-54$ & $8(2 \%)$ \\
\hline $55-64$ &
\end{tabular}

In addition to the basic demographic characteristics presented in Table 1, the respondents were asked about their frequency of travel. According to the data provided, 15 (3.7\%) respondents travel less than once every five years, 16 (3.9\%) of them travel once every five years, 22 (5.4\%) once every two years, and 104 (25.7\%) of them once a year. Most of the respondents, 232 (56.7\%) of them, said that they travel several times a year, with 14 (3.4\%) of them indicating their travel frequency to be once a month, and $6(1.5 \%)$ more often than once a month.

In order to test the hypotheses, the respondents were asked to express their level of agreement with 37 statements on a 5-point Likert scale (1 Strongly disagree; 5 - Strongly agree). Measures regarding the economic and the political situation, as well as product quality, have been adopted from Martin and Eroglu (1993), those regarding the level of technological development

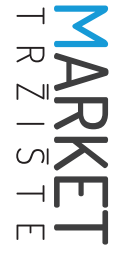

\section{Number (\%)}

\section{Education level $(n=409)$}

\begin{tabular}{|l|c|}
\hline Primary school & $3(0.75 \%)$ \\
\hline Secondary school & $83(20.29 \%)$ \\
\hline Bachelor's degree & $161(39.36 \%)$ \\
\hline Master's degree & $141(34.47 \%)$ \\
\hline Ph. D. & $21(5.13 \%)$ \\
\hline
\end{tabular}

\section{Monthly income in USD $(n=409)$}

\begin{tabular}{|l|c|}
\hline$<500$ & $70(17.1 \%)$ \\
\hline $501-1,500$ & $102(24.9 \%)$ \\
\hline $1,501-3,000$ & $83(20.3 \%)$ \\
\hline $3,001-5,000$ & $42(10.3 \%)$ \\
\hline $5,001-10,000$ & $58(14.2 \%)$ \\
\hline$>10,000$ & $54(13.2 \%)$ \\
\hline
\end{tabular}

from Allred et al. (1999), the level of industrialization and popularity from Lin and Chen (2006), the standard of living from Martin and Eroglu (1993), and Lin and Chen (2006), perceived safety from Martin and Eroglu (1993), and Chowdhury et al. (2017), and finally, those regarding knowledge from Lee and Ganesh (1999), and Maheswaran (1994).

SPSS was used for data analysis, with results presented in tabular form as well as descriptively. The results for each of the 37 statements for which respondents were asked to express their level of agreement are shown in Table 2. 


\section{TABLE 2: Hypothesis testing}

Statements

\section{Economic situation (S1 - S3)}

S1. Before my first visit to a destination, I research the current economic situation of the country in which it is located.

S2. The unstable economic situation of the country in which the destination is located will negatively affect my decision to choose that destination.

S3. When revisiting a destination, the economic situation of the country in which it is located is not important to me.

\section{Political situation (S4 - S8)}

S4. I prefer to visit countries with a lower unemployment rate.

S5. On my first visit to a destination, I research the current political situation of the country in which the destination is located.

S6. The unstable political situation of the country in which the destination is located will negatively affect my decision to choose the destination.

S7. I would rather visit a country with a democratic regime than a country organized in some other way.

S8. When I revisit a destination, the political situation of the country in which it is located is not important to me.

\section{Level of technological development (S9 - S11)}

S9. Before my first visit to a destination, I research the current level of technological development of the country in which it is located.

S10. I would rather visit a technologically advanced destination than a technologically underdeveloped one.

S11. If the destination is technologically underdeveloped, there is a high probability that I will never visit it.

\section{Level of industrialization (S12 - S14)}

S12. I believe the countries which are more industrially developed to be more polluted.

S13. Before my first visit to a destination, I research the current level of industrialization of the country in which the destination is located.

S14. I prefer to destinations that are less industrialized.

$m . v .=2.3936(t=-11.814 ; d f=408 ; p=0.000)$

$m . v .=3.2543(t=4.300 ; d f=408 ; p=0.000)$

$m . v .=2.8411(t=-2.890 ; d f=408 ; p=0.004)$

$m . v .=3.1394(t=2.466 ; d f=408 ; p=0.014)$

$m . v .=3.0318(t=0.570 ; d f=408 ; p=0.569)$

$m . v .=3.3447(t=6.385 ; d f=408 ; p=0.000)$

$m . v .=2.6993(t=-5.966 ; d f=408 ; p=0.000)$

$m . v .=3.3545(t=5.837 ; d f=408, p=0.000)$

$m . v .=3.6112(t=10.559 ; d f=408 ; p=0.000)$

$m \cdot v .=2.8411(t=-2.890 ; d f=408 ; p=0.004)$

t-test 


\begin{tabular}{|c|c|}
\hline Statements & t-test \\
\hline $\begin{array}{l}\text { S16. I would rather visit a more populous destination } \\
\text { than a sparsely populated one. }\end{array}$ & $m . v \cdot=2.5037(t=-9.577 ; d f=408 ; p=0.000)$ \\
\hline $\begin{array}{l}\text { S17. I prefer to visit destinations that are culturally } \\
\text { diverse from my country. }\end{array}$ & $m . v .=3.8704(t=18.895, d f=408 ; p=0.000)$ \\
\hline $\begin{array}{l}\text { S18. I prefer to visit destinations with less emphasized } \\
\text { social classes. }\end{array}$ & $m . v .=3.0733(t=1.426 ; d f=408 ; p=0.155)$ \\
\hline S19. I would not visit destinations with low labor costs. & $m . v .=2.1785(t=-18.042 ; d f=408 ; p=0.000)$ \\
\hline \multicolumn{2}{|l|}{ Product quality (S20 - S21) } \\
\hline $\begin{array}{l}\text { S20. If I have experience with products that come } \\
\text { from a certain country and I am satisfied with them, I } \\
\text { am more likely to visit a destination located in it. }\end{array}$ & $m . v .=3.0293(t=0.494 ; d f=408 ; p=0.621)$ \\
\hline $\begin{array}{l}\text { S21. I prefer to visit destinations that I associate with } \\
\text { quality products. }\end{array}$ & $m . v .=2.9291(t=-1.208 ; d f=408 ; p=0.228)$ \\
\hline \multicolumn{2}{|l|}{ Popularity (S22 - S25) } \\
\hline $\begin{array}{l}\text { S22. I prefer to visit destinations that are popular } \\
\text { among tourists. }\end{array}$ & $m . v .=3.0831(t=1.423 ; d f=408 ; p=0.155)$ \\
\hline $\begin{array}{l}\text { S23. I would rather visit destinations that a lot of my } \\
\text { friends and acquaintances have visited than those } \\
\text { they have not visited. }\end{array}$ & $m . v \cdot=2.9315(t=-1.132 ; d f=408 ; p=0.258)$ \\
\hline $\begin{array}{l}\text { S24. I spend less time researching destinations that } \\
\text { are advertised a lot. }\end{array}$ & $m . v .=2.8924(t=-1.932 ; d f=408 ; p=0.054)$ \\
\hline $\begin{array}{l}\text { S25. I'd rather visit a destination that is more heavily } \\
\text { advertised than the one that isn't advertised. }\end{array}$ & $m . v .=2.5550(t=-8.636 ; d f=408 ; p=0.000)$ \\
\hline \multicolumn{2}{|l|}{ Perceived safety (S26 - S27) } \\
\hline $\begin{array}{l}\text { S26. It is very important to me that the destination I } \\
\text { intend to visit is safe. }\end{array}$ & $m . v .=4.4108(t=33.783 ; d f=408 ; p=0.000)$ \\
\hline $\begin{array}{l}\text { S27. If I felt safe in a destination, I would visit it again } \\
\text { regardless of the general image of the country in } \\
\text { which it is located. }\end{array}$ & $m \cdot v .=4.0513(t=22.701, d f=408 ; p=0.000)$ \\
\hline \multicolumn{2}{|l|}{ Knowledge (S28 - S37) } \\
\hline $\begin{array}{l}\text { S28. It is much easier for me to decide to visit a } \\
\text { destination that I have heard a lot about. }\end{array}$ & $m . v .=4.0538(t=24.738 ; d f=408 ; p=0.000)$ \\
\hline $\begin{array}{l}\text { S29. When I visit a destination again, I spend much } \\
\text { less time researching the characteristics of the } \\
\text { country in which it is located. }\end{array}$ & $m . v .=3.8509(t=17.295 ; d f=408 ; p=0.000)$ \\
\hline $\begin{array}{l}\text { S30. When I visit a destination again, the } \\
\text { characteristics of the country in which it is located are } \\
\text { not so important to me. }\end{array}$ & $m . v .=3.3912(t=7.268 ; d f=408 ; p=0.000)$ \\
\hline $\begin{array}{l}\text { S31. For well-known destinations, the image of the } \\
\text { country in which the destination is located is not } \\
\text { important to me. }\end{array}$ & $m . v .=3.1638(t=3.061 ; d f=408 ; p=0.002)$ \\
\hline $\begin{array}{l}\text { S32. The experience and knowledge I gained about } \\
\text { the destination during the visit itself will have a } \\
\text { much greater impact on my decision to revisit it than } \\
\text { information gathered through the media. }\end{array}$ & $m \cdot v \cdot=4.3814(t=35.513 ; d f=408 ; p=0.000)$ \\
\hline
\end{tabular}




\begin{tabular}{|l|l|}
\hline Statements & \multicolumn{1}{|c|}{ t-test } \\
\hline $\begin{array}{l}\text { S33. If there is not much information available about } a \\
\text { destination, I rely on the knowledge I have about the } \\
\text { country in which it is located. }\end{array}$ & $m . v .=3.7237(t=17.132 ; d f=408 ; p=0.000)$ \\
\hline $\begin{array}{l}\text { S34. If I have a poor opinion of the country in which } \\
\text { a destination is located, I am less likely to visit the } \\
\text { destination. }\end{array}$ & $m . v .=3.7800(t=16.047 ; d f=408 ; p=0.000)$ \\
\hline $\begin{array}{l}\text { S35. I think that I am generally well informed about } \\
\text { the offer of tourist destinations (most popular, most } \\
\text { affordable, having the best entertainment...). }\end{array}$ & $m . v .=3.3667(t=6.874 ; d f=408 ; p=0.000)$ \\
\hline $\begin{array}{l}\text { S36. I rely more on my own knowledge and } \\
\text { information about a destination than on information } \\
\text { provided to me by others. }\end{array}$ & $m \cdot v .=3.2469(t=4.798 ; d f=408 ; p=0.000)$ \\
\hline $\begin{array}{l}\text { S37. When evaluating a new destination, I usually } \\
\text { rely on knowledge of the country in which the } \\
\text { destination is located. }\end{array}$ & $m . v .=3.2983(t=6.205 ; d f=408 ; p=0.000)$ \\
\hline
\end{tabular}

According to the results presented in Table 2, the respondents agree with the statements regarding the political situation and perceived safety and their importance in DBB. Therefore, $\mathrm{H} 2$ and $\mathrm{H} 8$ can be accepted. Also, the results indicate that a higher level of consumer knowledge about the destination reduces the importance of $\mathrm{COO}$ as a factor of DBB. H9 can, therefore, also be accepted.

On the other hand, the respondents do not think that the economic situation, level of tech- nological development and industrialization, the standard of living, product quality, and popularity of the destination's $\mathrm{COO}$ are important in DBB. Because of this, hypotheses $\mathrm{H1}, \mathrm{H3}, \mathrm{H} 4, \mathrm{H} 5$, $\mathrm{H6}$, and $\mathrm{H7}$ cannot be accepted.

Table 3 lists the hypotheses with corresponding designations of the statement used to test them and presents the results of the hypothesis testing.

\section{TABLE 3: Hypothesis testing}

\begin{tabular}{|c|c|}
\hline Hypothesis & $\begin{array}{l}\text { Testing } \\
\text { result }\end{array}$ \\
\hline H1: Favorable economic situation of a destination's COO is important for favorable DBB. & Rejected \\
\hline H2: Favorable political situation of a destination's COO is important for favorable DBB. & Accepted \\
\hline $\begin{array}{l}\text { H3: Favorable level of technological development of a destination's COO is important } \\
\text { for favorable DBB. }\end{array}$ & Rejected \\
\hline $\begin{array}{l}\text { H4: Favorable level of industrialization of a destination's COO is important for favorable } \\
\text { DBB. }\end{array}$ & Rejected \\
\hline H5: Favorable standard of living of a destination's COO is important for favorable DBB. & Rejected \\
\hline H6: Favorable product quality of a destination's COO is important for favorable DBB. & Rejected \\
\hline H7: Favorable popularity of a destination's COO is important for favorable DBB. & Rejected \\
\hline H8: Favorable perceived safety of a destination's COO is important for favorable DBB. & Accepted \\
\hline $\begin{array}{l}\text { H9: Greater knowledge of the destination brand reduces the importance of the } \\
\text { destination's COO for DBB. }\end{array}$ & Accepted \\
\hline
\end{tabular}




\section{DISCUSSION}

COO does not influence DBB in the same way it influences product/service branding. In the case of DBB, the results indicate that the $\mathrm{COO}$ of a destination is important in terms of stability of the political situation and safety. No other COO dimensions seem to have a substantial influence as tourists seek the authentic local experience. Therefore, most of the COO dimensions, which are important for the product/service brand, have no such value in the case of DBB. For example, although previous research (Piron, 2000) shows that the perceived product quality of a $\mathrm{COO}$ will affect the product brand positively, it is not significant in the case of destination branding ( $(\mathrm{H} 6)$.

Political situation $(\mathrm{H} 2)$ and perceived safety $(\mathrm{H} 8)$ were found to be the only two $\mathrm{COO}$ attributes relevant for $\mathrm{DBB}$. When visiting a destination, one needs to be "in situ", so everyone seeks destination safety. The importance of political stability also proved relevant as it can be seen as a precondition for safety, which is in line with the previous research results of Samitas, Asteriou, Polyzos, and Kenourgios (2018), and Buda (2016). This implies that the destination whose COO image is one of a politically stable and safe country should use this as a building block in destination branding to gain a competitive advantage.

Regions around the world all recorded tourism growth in the last several years (www2.unwto. org), which means that developing countries and countries in transition have also become attractive tourist destinations. Therefore, it is not surprising that the economic situation, level of technological development and industrialization, and, consequently, the standard of living were not found to be essential attributes for DBB. However, those attributes are related to political stability and safety (Uddin, Ali \& Masih, 2017; Georgioua, Kyriazisb \& Economouc, 2015), which are in fact important for DBB, so those countries should not ignore them in the long run. Also, some developing countries and countries in transition tend not to have continuity in terms of political stability and safety, which implies that their destinations (e.g., cities, resorts) should not use COO as an attribute in brand building.

An unexpected finding is that the popularity of the destination's $\mathrm{COO}$ is not important for the local destination brand. We found justification for such a finding in over-globalization and consumers' growing desire for unique experiences. Tolkach and Pratt (2021), and Stalmirska (2021) observed the impact of the globalization process on lessening cultural differences and food specificities, while Yu, Byun, and Lee (2014) found that a high level of globalization leads to fewer hotels reflecting local culture. With this in mind, and based on the finding that tourists are looking for unique and unexpected personal experiences in a destination (Park \& Santos, 2017), we posit that the popularity of the destination's COO may not be important for DBB.

Finally, knowledge about the destination diminishes the role of the COO. According to Schaefer (1995), COO is not as critical for consumers who are familiar with the brand through education, personal experience, or people they trust. This is supported by the results of this research study. Namely, the respondents exhibited the most positive attitude with respect to the statement that the information and experience they gained as tourists during their first visit will influence their decision to repeat the visit to the destination most (m.v.=4.3814). This implies that destinations with an unfavorable $\mathrm{COO}$ image should facilitate positive experiences and their sharing, focusing primarily on fostering positive word-of-mouth regarding the destination's stability and safety. They should also provide detailed information to enhance tourist knowledge about the destination, thereby diminishing potential negative influences on the $\mathrm{COO}$.

Additionally, we tested for the difference between the attitudes of Croatian and U.S. respondents, the results of which are presented in Table 4 in the Appendix. A statistically significant difference was found between Croatian and U.S. respondents with regard to 27 out of 


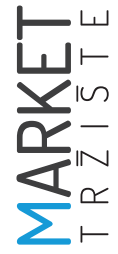

the 37 statements. Nevertheless, most of the statements resulted in a different level of agreement but still in the same direction. Differences regarding the statements with the opposite direction were found only in the case of economic situation and product quality as $\mathrm{COO}$ dimensions. More precisely, economic situation and product quality were found to be important for DBB among U.S. respondents, while this was not the case for Croatian respondents. This finding highlights the importance of analyzing the $\mathrm{COO}$ influence on DBB at country level, pointing to possible differences resulting from the motives for travel and habits of tourists from different economic, cultural, political, and geographical environments. As such, these results may also serve as a suggestion and starting point for future research streams.

\section{CONCLUSIONS}

Building a positive, long-lasting $\mathrm{COO}$ image is a task that is faced by every country engaged in international business. A favorable COO image has a positive impact on greater market recognition and perception of the country's products or services. Therefore, the goal of every country must be to build and maintain the best possible image as a $\mathrm{COO}$, which can be quite a challenge in the constantly changing and unpredictable environment nowadays. As tourism becomes an essential industry for many countries, building a recognizable and unique destination brand has become crucial. Leaving the formation of the destination brand image to the market and not managing it in the hypercompetitive current environment is destined to failure. It is, therefore, essential to consider and research the factors that influence DBB. Given that a destination, or a specific place, is the subject of exchange in international marketing, just as a product or service is, it is advisable and necessary to investigate how the destination's $\mathrm{COO}$ influences the DBB.

Although much prior research has shown that the COO influences the product/service brand image, this paper contributes to the marketing theory by revealing a limited effect of the COO on DBB. In this study, the COO construct was decomposed into building blocks, with the research results showing that only the political situation and safety impact the DBB. In contrast, the economic situation, product quality, and the level of technological development did no tprove to be so important. These findings lead to the conclusion that it is the COO factors which can directly affect consumer experience in a destination, such as the political situation, cultural diversity, security, etc., that are critical for DBB.

Another contribution of this paper consists in the finding that consumer knowledge about a destination (whether subjective/objective knowledge or brand awareness) reduces the importance of the destination's $\mathrm{COO}$ as a factor in DBB. This has a crucial managerial implication for the stakeholders in charge of DBB, implying that an unfavorable COO image does not necessarily mean the destination brand image will automatically be negative. It is important to have a strategy to deal with such a situation and present such information to potential tourists that will enhance their knowledge and positive attitude toward the destination and, in turn, help reduce the impact of any unfavorable COO image.

Although many dimensions of the $\mathrm{COO}$ construct seem to be less relevant for DBB, the dimensions of safety and political stability must not be overlooked. Since these two dimensions represent fundamental precursors in considering a destination at all, this is where the $\mathrm{COO}$ plays a vital role for DBB. Furthermore, the two dimensions are increasingly important in the context of the COVID-19 pandemic, as tourists rely on the $\mathrm{COO}$ to cope with the high ambiguity and uncertainty surrounding the pandemic situation.

The convenience sample applied represents the main limitation of the research. Also, the questionnaire was distributed solely to digitally literate respondents through Facebook and Linkedln social networks. Thus, the sample con- 
sisted of persons with similar characteristics and interests, which increased the possibility of similar attitudes among the respondents.

With regard to future research, it would be interesting to explore the importance of the elements of the $\mathrm{COO}$ construct in DBB for different types of tourism, e.g., health tourism, religious tourism, gastro-tourism. In addition, exploring whether consumers' financial or cultural background influences the perception of $\mathrm{COO}$ importance in DBB would be beneficial for destination brand management and destination offering.

\section{Acknowledgment}

This paper has made use of data collected in a research project undertaken as part of the final thesis of student Mateja Mirt.

\section{References}

1. Allred, A., Chakraborty, G., \& Miller, S. (1999). Measuring Images of Developing Countries: A Scale Development Study. Journal of Euromarketing, 8(1), 29-49.

2. Alvarez, M. D., \& Campo, S. (2014). The influence of political conflicts on country image and intention to visit: A study of Israel's image. Tourism Management, 40, 70-78.

3. Ar, A. A., \& Kara, A. (2014). Emerging market consumers' country of production image, trust and quality perceptions of global brands made-in China. Journal of Product \& Brand Management, 23(7), 491-503.

4. Araña, J. E., \& León, C. J. (2008). The impact of terrorism on tourism demand. Annals od Tourism Reseearch, 35(2), 299-315.

5. Baker. D. (2014). The Effects of Terrorism on the Travel and Tourism Industry. The international journal of religious tourism and pilgrimage, 2(1), 58-67.

6. Balakrishnan, M., S., Nekhili, R., \& Lewis, C. (2011). Destination brand components. International Journal of Culture, Tourism and Hospitality Research, 5(1), 4-25.

7. Batat, W. (2021). The role of luxury gastronomy in culinary tourism: An ethnographic study of Michelin-Starred restaurants in France. International Journal of Tourism Research, 23(2), 150-163.

8. Bérenger, V., \& Verdier-Chouchane, A. (2007). Multidimensional Measures of Well-Being: Standard of Living and Quality of Life Across Countries. World Development, 35(7), 1259-1276.

9. Bilkey, W. J., \&Nes, E. (1982). Country of origin effects on product evaluation. Journal of International Business Studies, 8(1), 89-99.

10. Blain, C., Levy, S., \& Ritchie, B. (2005). Destination Branding: Insights and Practies from Destination Management Organization. Journal of Travel Research, 43, 328-338.

11. Boo, S., Busser, J., \& Baloglu, S. (2009). A model of customer-based brand equity and its application to multiple destinations. Tourism Management, 30, 219-231.

12. Brahmasrene, T., \&Wan Lee, J. (2017). Assessing the dynamic impact of tourism, industrialization, urbanization, and globalization on growth and environment in Southeast Asia. International Journal of Sustainable Development \& World Ecology, 24(4), 362-371.

13. Buda, D. M. (2016). Tourism in Conflict Areas: Complex Entanglements in Jordan. Journal of Travel Research, 55(7), 835-846.

14. Buhalis, D., \& Law, R. (2008). Progress in information technology and tourism management: 20 years on and 10 years after the Internet-The state of eTourism research. Tourism Management, 29(4), 609-623.

15. Buhalis, D., \& O'Connor, P. (2005). Information Communication Technology Revolutionizing Tourism. Tourism Recreation Research, 30(3), 7-16. 
16. Cherniwchan, J. (2012). Economic growth, industrialization, and the environment. Resource and Energy Economics, 34(4), 442-467.

17. Chowdhury, A., Raj, R., Griffin, K. A., \& Clarke, A. (2017). Terrorism, tourism and religious travellers. International Journal of Religious Tourism and Pilgrimage, 5(1), 1-19.

18. Diamantopoulos, A., Schlegelmilch, B., \& Palihawadana, D. (2011). The relationship between country-of-origin image and brand image as drivers of purchase intentions. International Marketing Review, 28(5), 508-524.

19. Dowrick, S., Dunlop, Y., \& Quiggin, J. (2003). Social indicators and comparisons of living standards. Journal of Development Economics, 70(2), 501-529.

20. Echtner, C., \& Ritchie, J. R. (2003). The Meaning and Measurement of Destination Image. Journal of Tourism studies, 14(1), 37-48.

21. Erickson, G., M., Johansson, J., \& Chao, P. (1984). Image Variables in Multi - Attribute Product Evaluations: Country-of-origin Effects. Journal of Consumer Research, 11(2), 694-699.

22. Gartner, W. C. (2014). Brand equity in a tourism destination. Place Branding and Public Diplomacy, 10, 108-116.

23. Georgioua, M. N., Kyriazisb, N., \& Economouc, E. M. L. (2015). Democracy, Political Stability and Economic performance. A Panel Data Analysis. Journal of Risk \& Control, 2(1), 1-18.

24. Godey, B., Pederzoli, D., Aiello, G., Donvito, R., Chan, P., Oh, H., Singh, R., Skorobogatykh Ivanovna, I., Tsuchiya, J., \& Weitz, B. (2012). Brand and country-of-origin effect on consumers' decision to purchase luxury products. Journal of Business Research, 65, 1461-1470

25. Han, C. M. (1989). Country image: halo or summary construct?. Journal of Marketing Research, 26, 222-229.

26. Han, C. M., \& Terpstra, V. (1988). Country-of-Origin Effects for Uni-National and Bi-National Products. Journal of International Business Studies, 19(2), 235-255.

27. Jadhav, V. S., \& Mundhe, S. D. (2011). Information technology in Tourism. International Journal of Computer Science and Information Technologies, 2(6), 2822-2825.

28. Jalilvand, M., Samiei, N., \& Dini, B. (2012). Examining the structural relationships of electronic word of mouth, destination image, tourist attitude toward destination and travel intention: An integrated approach. Journal of Destination Marketing \& Management, 1(1/2), 134-143.

29. Kaynak, E., Kucukemiroglu, O., \& Hyder, A.S. (2000). Consumers' country-of-origin (COO) perceptions of imported products in a homogenous less-developed country. European Journal of Marketing, 34(9/10), 1221-1241.

30. Kinley, T. R., Forney, J. A., \& Kim, Y-K. (2012). Travel motivation as a determinant of shopping venue. International Journal of Culture, Tourism and Hospitality Research, 6(3), 266-278.

31. Kirchler, E., Fischer, F., \& Hölzl, E. (2010). Price and its Relation to Objective and Subjective Product Quality: Evidence from the Austrian Market. Journal of Consumer Policy, 33, 275-286.

32. Klein, J. G., Ettenson, R., \& Krishnan, B. C. (2006). Extending the construct of consumer ethnocentrism: When foreign products are preferred. International Marketing Review, 23(3), 304-321.

33. Lee, D., \& Ganesh, G. (1999). Effects of partitioned country image in the context of brand image and familiarity. International Marketing Review, 16(1), 18-41.

34. Lin, L., \& Chen, C. (2006). The influence of the country-of-origin image, product knowledge and product involvement on consumer purchase decisions: an empirical study of insurance and catering services in Taiwan. Journal of Consumer Marketing, 23(5), 248-265.

35. Listiana, E. (2015). Country of Origin Image and It's Impact on Brand Association, Percieved Quality and Brand Loyalty. Journal of Marketing and Consumer Research, 10, 19-29.

36. Maheswaran, D. (1994). Country of origin as a stereotype: effects of consumer expertise and attribute strength on product evaluations. Journal of Consumer Research, 21(2), 354-365. 
37. Martin, I., \& Eroglu, S. (1993). Measuring a multi-dimensional construct: Country image. Journal of Business Research, 28, 191-210.

38. Meng, J., Nasco, S. A., \& Clark, T. (2007). Measuring Country-of-Origin Effects in Caucasians, African-Americans and Chinese Consumers for Products and Services. Journal of International Consumer Marketing, 20(2), 17-31.

39. Morakabati, A. (2013). Tourism in the Middle East: Conflicts, Crises and Economic Diversification, Some Critical Issues. International Journal of Tourism Research, 15(4), 375-387.

40. Muhamad, N., Leong, V. S., \& Isa, N. M. (2017). Does the country of origin of a halal logo matter? The case of packaged food purchases. Review of International Business and Strategy, 27(4), 484500.

41. Nadeau, J., Heslop, L., O'Reilly, N., \& Luk, P. (2008). Destination in a Conutry Image Context. Annals of Topurism Research, 35(1), 84-106.

42. Nagashima, A. (1970). A comparative "Made In" Product Image Survey Among Japanese Businessmen. Journal of Marketing, 41(3), 95-100.

43. Navío-Marco, J., Ruiz-Gómez, L., M., \& Sevilla-Sevilla, C. (2018). Progress in information technology and tourism management: 30 years on and 20 years after the internet - Revisiting Buhalis \& Law's landmark study about eTourism. Tourism Management, 69, 460-470.

44. Ozretic-Dosen, D., Previsic, J., Krupka, Z., Skare, V., \& Komarac, T. (2018). The role of familiarity in the assessment of Turkey's country/destination image: going beyond soap operas. International Journal of Culture, Tourism and Hospitality Research, 12(3), 277-291.

45. Ozsomer, A., \& Cavusgil, S. (1991). Country of origin effects on product evaluations. AMA Educators Proceedings, 2, 269-277.

46. Pappu, R., Quester, P., \& Cooksey, R. (2007). Country image and consumer - based brand equity: Relationships and implications for international marketing. Journal of International Business Studies, 38(5), 726-745.

47. Pecotich, A., \& Rosenthal, M. J. (2001). Country of origin, quality, brand and consumer eethnocentrism. Journal of Global Marketing, 15(2), 31-60.

48. Pereira, A., Hsu, C-C., \& Kundu, S. K. (2005). Country-of-origin image: measurement and crossnational testing. Journal of Business Research, 58(1), 103-106.

49. Pike, S. (2004). Destination Marketing Organizations. Oxford: Elsevier

50. Piron, F. (2000). Consumers` perceptions of the country-of-origin effects on purchasing intentions of (in)conspicuous products. Journal of Consumer Marketing, 17(4), 308-321.

51. Ritchie, B., \& Ritchie, R. (1998). The Branding of tourism destination. Annual Congress of the International Association of Scientific Experts in Tourism, Morocco.

52. Roth, M. S., \& Romeo, J. B. (1992). Matching product category and country image perceptions: a framework for managing country-of-origin effects. Journal of International Business Studies, 23(3), 477-497.

53. Saha, S., \& Yap, G. (2014). The Moderation Effects of Political Instability and Terrorism on Tourism Development: A Cross-Country Panel Analysis. Journal of Travel Research, 53(4), 509-521.

54. Samitas, A., Asteriou, D., Polyzos, S., \& Kenourgios, D. (2018). Terrorist incidents and tourism demand: Evidence from Greece. Tourism Management Perspectives, 25, 23-28.

55. Par, S., \& Santos, C. A. ( 2017). Exploring the Tourist Experience: A Sequential Approach. Journal of Travel Research, 56(1), 16-27.

56. Schaefer, A. (1995). Consumer knowledge and country of origin effects. Journal of Marketing, $31(1), 56-72$.

57. Schooler, R. D. (1965). Product bias in the central American common market. Journal of Marketing Research, 2(4), 394-397. 
58. Stalmirska, A. M. (2021). Cultural globalisation and food in urban destination marketing. Tourism Geographies, 23(on-line).

59. Tasci, A. D. A., Gartner, W. C., \& Cavusgil, S. T. (2007). Measurement of destination brand bias using a quasi-experimental design. Tourism Management, 28, 1529-1540.

60. Tolkach, D., \& Pratt, S. (2021). Globalisation and cultural change in Pacific Island countries: the role of tourism. Tourism Geographies, 23(3), 371-396.

61. Tóth, G., Dávid, L. D., \& Vasa, L. (2014). The role of transport in European tourism flows. Acta geographica Slovenica, 54(2), 311-320.

62. Uddin, A., Ali, H., \& Masih, M. (2017). Political stability and growth: An application of dynamic GMM and quantile regression. Economic Modelling, 64, 610-625.

63. Veasna, S. (2013). The Impact of Destination Source Credibility on Destination Satisfaction: The Mediating Effects of Destination Attachment and Destination Image. Journal of Tourism Management, 36, 511-526.

64. World Tourism Organization, www2.unwto.org

65. Xiang, Z. (2018). From digitization to the age of acceleration: On information technology and tourism. Tourism Management Perspective, 25, 147-150.

66. Yasin, N. M., Noor, M. N., \& Mohamad, O. (2007). Does image of country-of-origin matter to brand equity?. Journal of Product and Brand Management, 16(1), 38-48.

67. Yu, Y., Byun, W-H., \& Lee, T. J. (2014). Critical issues of globalisation in the international hotel industry. Current Issues in Tourism, 17(2), 114-118.

68. Zou, Y., \& Meng, F. (2020). Chinese tourists' sense of safety: perceptions of expected and experienced destination safety. Current Issues in Tourism, 23(15), 1886-1899.

\section{Appendix}

TABLE 4: Comparison of Croatian and USA respondents' attitudes

\begin{tabular}{|c|c|c|c|}
\hline Statements & $\begin{array}{c}\text { Croatia } \\
\text { (m.v.) }\end{array}$ & $\begin{array}{l}\text { USA } \\
(\mathbf{m . v .})\end{array}$ & t-test \\
\hline \multicolumn{4}{|l|}{ Economic situation (S1 - S3) } \\
\hline $\begin{array}{l}\text { S1. Before my first visit to a destination, I research the current } \\
\text { economic situation of the country in which it is located. }\end{array}$ & 2.8972 & 3.3865 & $p=0.000$ \\
\hline $\begin{array}{l}\text { S2. The unstable economic situation of the country in which } \\
\text { the destination is located will negatively affect my decision } \\
\text { to choose that destination. }\end{array}$ & 2.7523 & 3.3188 & $p=0.000$ \\
\hline $\begin{array}{l}\text { S3. When revisiting a destination, the economic situation of } \\
\text { the country in which it is located is not important to me. }\end{array}$ & 3.5607 & 3.1256 & $p=0.000$ \\
\hline \multicolumn{4}{|l|}{ Political situation (S4 - S8) } \\
\hline S4. I prefer to visit countries with a lower unemployment rate. & 2.5093 & 2.8744 & $p=0.000$ \\
\hline $\begin{array}{l}\text { S5. On my first visit to a destination, I research the current } \\
\text { political situation of the country in which the destination is } \\
\text { located. }\end{array}$ & 3.0467 & 3.6908 & $p=0.000$ \\
\hline $\begin{array}{l}\text { S6. The unstable political situation of the country in which } \\
\text { the destination is located will negatively affect my decision } \\
\text { to choose the destination. }\end{array}$ & 3.2617 & 3.9517 & $p=0.000$ \\
\hline $\begin{array}{l}\text { S7. I would rather visit a country with a democratic regime } \\
\text { than a country organized in some other way. }\end{array}$ & 3.0981 & 3.4155 & $p=0.012$ \\
\hline
\end{tabular}




\begin{tabular}{|c|c|c|c|}
\hline Statements & $\begin{array}{l}\text { Croatia } \\
\text { (m.v.) }\end{array}$ & $\begin{array}{l}\text { USA } \\
(\mathbf{m . v .})\end{array}$ & t-test \\
\hline $\begin{array}{l}\text { S8. When I revisit a destination, the political situation of the } \\
\text { country in which it is located is not important to me. }\end{array}$ & 3.0888 & 2.6329 & $p=0.000$ \\
\hline \multicolumn{4}{|l|}{ Level of technological development (S9 - S11) } \\
\hline $\begin{array}{l}\text { 59. Before my first visit to a destination, I research the } \\
\text { current level of technological development of the country } \\
\text { in which it is located. }\end{array}$ & 2.3065 & 2.5217 & $p=0.241$ \\
\hline $\begin{array}{l}\text { S10. I would rather visit a technologically advanced } \\
\text { destination than a technologically underdeveloped one. }\end{array}$ & 2.1682 & 2.9072 & $p=0.000$ \\
\hline $\begin{array}{l}\text { S11. If the destination is technologically underdeveloped, } \\
\text { there is a high probability that I will never visit it. }\end{array}$ & 1.7757 & 2.6522 & $p=0.225$ \\
\hline \multicolumn{4}{|l|}{ Level of industrialization (S12 - S14) } \\
\hline $\begin{array}{l}\text { S12. I believe the countries which are more industrially } \\
\text { developed to be more polluted. }\end{array}$ & 3.2383 & 3.7923 & $p=0.000$ \\
\hline $\begin{array}{l}\text { S13. Before my first visit to a destination, I research the } \\
\text { current level of industrialization of the country in which the } \\
\text { destination is located. }\end{array}$ & 2.4514 & 2.2493 & $p=0.316$ \\
\hline S14. I prefer to destinations that are less industrialized. & 2.7785 & 2.7406 & $p=0.683$ \\
\hline \multicolumn{4}{|l|}{ Standard of living (S15 - S19) } \\
\hline $\begin{array}{l}\text { S15. I prefer to visit destinations with a higher GDP per } \\
\text { capita. }\end{array}$ & 2.5194 & 2.5031 & $p=0.795$ \\
\hline $\begin{array}{l}\text { S16. I would rather visit a more populous destination than a } \\
\text { sparsely populated one. }\end{array}$ & 2.8196 & 2.1353 & $p=0.648$ \\
\hline $\begin{array}{l}\text { S17. I prefer to visit destinations that are culturally diverse } \\
\text { from my country. }\end{array}$ & 3.7196 & 3.9894 & $p=0.089$ \\
\hline $\begin{array}{l}\text { S18. I prefer to visit destinations with less emphasized social } \\
\text { classes. }\end{array}$ & 2.9346 & 3.3420 & $p=0.000$ \\
\hline S19. I would not visit destinations with low labor costs. & 1.8738 & 2.2222 & $p=0.000$ \\
\hline \multicolumn{4}{|l|}{ Product quality (S20 - S21) } \\
\hline $\begin{array}{l}\text { S20. If I have experience with products that come from a } \\
\text { certain country and I am satisfied with them, I am more } \\
\text { likely to visit a destination located in it. }\end{array}$ & 2.7196 & 3.3575 & $p=0.000$ \\
\hline $\begin{array}{l}\text { S21. I prefer to visit destinations that I associate with quality } \\
\text { products. }\end{array}$ & 2.6542 & 3.2077 & $p=0.000$ \\
\hline \multicolumn{4}{|l|}{ Popularity (S22 - S25) } \\
\hline $\begin{array}{l}\text { S22. I prefer to visit destinations that are popular among } \\
\text { tourists. }\end{array}$ & 3.1028 & 3.0435 & $p=0.609$ \\
\hline $\begin{array}{l}\text { S23. I would rather visit destinations that a lot of my friends } \\
\text { and acquaintances have visited than those they have not } \\
\text { visited. }\end{array}$ & 2.8271 & 3.0145 & $p=0.116$ \\
\hline $\begin{array}{l}\text { S24. I spend less time researching destinations that are } \\
\text { advertised a lot. }\end{array}$ & 2.9112 & 2.8737 & $p=0.874$ \\
\hline $\begin{array}{l}\text { S25. I'd rather visit a destination that is more heavily } \\
\text { advertised than the one that isn't advertised. }\end{array}$ & 2.5374 & 2.5556 & $p=0.859$ \\
\hline
\end{tabular}




\begin{tabular}{|c|c|c|c|}
\hline Statements & $\begin{array}{l}\text { Croatia } \\
(\mathrm{m.v.})\end{array}$ & $\begin{array}{l}\text { USA } \\
(\mathrm{m.v.})\end{array}$ & t-test \\
\hline \multicolumn{4}{|l|}{ Perceived safety (S26 - S27) } \\
\hline $\begin{array}{l}\text { S26. It is very important to me that the destination I intend } \\
\text { to visit is safe. }\end{array}$ & 4.3037 & 4.5121 & $p=0.011$ \\
\hline $\begin{array}{l}\text { S27. If I felt safe in a destination, I would visit it again } \\
\text { regardless of the general image of the country in which it is } \\
\text { located. }\end{array}$ & 4.0421 & 4.0628 & $\mathrm{p}=0.818$ \\
\hline \multicolumn{4}{|l|}{ Knowledge (S28 - S37) } \\
\hline $\begin{array}{l}\text { S28. It is much easier for me to decide to visit a destination } \\
\text { that I have heard a lot about. }\end{array}$ & 4.0140 & 4.0773 & $p=0.452$ \\
\hline $\begin{array}{l}\text { S29. When I visit a destination again, I spend much less time } \\
\text { researching the characteristics of the country in which it is } \\
\text { located. }\end{array}$ & 3.8271 & 3.8551 & $\mathrm{p}=0.772$ \\
\hline $\begin{array}{l}\text { S30. When I visit a destination again, the characteristics of } \\
\text { the country in which it is located are not so important to } \\
\text { me. }\end{array}$ & 3.5654 & 3.2029 & $p=0.001$ \\
\hline $\begin{array}{l}\text { S31. For well-known destinations, the image of the country } \\
\text { in which the destination is located is not important to me. }\end{array}$ & 3.4112 & 2.9179 & $p=0.000$ \\
\hline $\begin{array}{l}\text { S32. The experience and knowledge I gained about the } \\
\text { destination during the visit itself will have a much greater } \\
\text { impact on my decision to revisit it than information } \\
\text { gathered through the media. }\end{array}$ & 4.4159 & 4.2995 & $p=0.141$ \\
\hline $\begin{array}{l}\text { S33. If there is not much information available about a } \\
\text { destination, I rely on the knowledge I have about the } \\
\text { country in which it is located. }\end{array}$ & 3.6822 & 3.7585 & $p=0.0360$ \\
\hline $\begin{array}{l}\text { S34. If I have a poor opinion of the country in which a } \\
\text { destination is located, I am less likely to visit the destination. }\end{array}$ & 3.7710 & 3.7874 & $p=0.863$ \\
\hline $\begin{array}{l}\text { S35. I think that I am generally well informed about the } \\
\text { offer of tourist destinations (most popular, most affordable, } \\
\text { having the best entertainment...). }\end{array}$ & 3.4813 & 3.2560 & $p=0.030$ \\
\hline $\begin{array}{l}\text { S36. I rely more on my own knowledge and information } \\
\text { about a destination than on information provided to me by } \\
\text { others. }\end{array}$ & 3.3084 & 3.1787 & $p=0.200$ \\
\hline $\begin{array}{l}\text { S37. When evaluating a new destination, I usually rely } \\
\text { on knowledge of the country in which the destination is } \\
\text { located. }\end{array}$ & 3.2944 & 3.2995 & $\mathrm{p}=0.957$ \\
\hline
\end{tabular}

